Article

\title{
Evaluation of Third Party Logistics Providers Considering Social Sustainability
}

\author{
Hosang Jung \\ Asia Pacific School of Logistics, Inha University, 100 Inha-ro, Nam-gu, Incheon 402-751, Korea; \\ hjung@inha.ac.kr; Tel.: +82-32-860-8435 \\ Academic Editor: Fabio Carlucci \\ Received: 20 January 2017; Accepted: 6 May 2017; Published: 9 May 2017
}

\begin{abstract}
In this paper, we investigated a third-party logistics (3PL) provider evaluation problem considering social sustainability as one of the important evaluation criteria. Since the 3PL service is mainly dependent on both transport vehicles and employees, managing them from the viewpoint of social sustainability has become a critical issue. Thus, 3PL providers need to be concerned about not only the service price or quality but also issues related to social sustainability. In line with this trend, we defined the social sustainability of 3PL providers and related evaluation criteria. In addition, a fuzzy analytic hierarchy process (AHP) was used as a main evaluation framework to help decision-makers determine the relative importance of each criteria or alternative using linguistic terms. To show the feasibility of the proposed criteria and evaluation framework, we presented the illustrative example based on a real-world case. The results showed that the proposed approach could be a good alternative to conduct evaluations, and the related sensitivity analysis, considering social sustainability.
\end{abstract}

Keywords: third-party logistics service; social sustainability; fuzzy analytic hierarchy process

\section{Introduction}

A third-party logistics (3PL) provider is an external provider who manages, controls, and delivers logistics activities on behalf of a shipper [1]. A 3PL provider collects outbound shipments from manufacturers and consolidates shipments in their distribution centers. The consolidated shipments are then moved via alternative transportation routes to the customer zones [2]. The most frequently cited benefit of using a 3PL provider is that it allows a manufacturer to focus on its competencies [3]. The 3PL alliances between manufacturers and professional logistics providers can be found in many real-world cases [4-6].

The evaluation of the 3PL providers is a critical step for a manufacturer seeking to select an appropriate 3PL provider as a business partner. The firm (i.e., shipper) can determine the relative weights of the 3PL providers and allocate its transporting volumes to the selected 3PL provider who has a highest weight. In general, the 3PL provider evaluation is a multi-criteria problem and thus a complex process in which multiple criteria, both tangible and intangible, must be considered [7]. In other words, choosing the right 3PL provider involves much more than scanning a series of pricelists. A great deal of research on the 3PL provider evaluation has been conducted previously [8-14], and various evaluation criteria have been developed so far. According to the Pareto analysis of Aguezzoul [7], the most commonly used criteria are as follows: cost, relationship, services, quality, information/equipment system, flexibility (i.e., ability to adapt to changing customers' requirements and circumstances), and delivery (i.e., on-time delivery performance).

However, among the frequently used criteria from previous literature, those related to business sustainability are rarely found. Business sustainability is defined as the ability to conduct business 
with a long-term goal of maintaining the well-being of the economy, environment, and society [15]. As this business sustainability has become a competitive differentiator, many firms are eager to incorporate sustainability into their operations management. As Lieb and Lieb indicate [16], despite the importance of sustainable operations in a 3PL provider, it seems that sustainable issues are not the major determining factor in the 3PL contractual agreements. While increasing numbers of customers are now demanding sustainable operations from firms including the 3PL providers, the shipper's stimuli for the sustainable operations of the 3PL provider are still underdeveloped [17].

In particular, although the topic of sustainable operations has been of great interest for the last decade in both academia and industry, social sustainability has been examined to a far lesser degree than environmental or green operations management issues [18,19]. In comparison with the environmental sustainability, the definition of social sustainability itself is not clearly established despite its importance [20]. Including social concerns into sustainable operations raises many modeling and assessment difficulties [21]. In other words, generating the pertinent quantitative indicators that can be used to formulate the related model or approach is difficult. Nevertheless, some researchers have tried to generate the related indicators, such as the firm's activities, to improve working conditions for its employees and the enhancement of qualified employment via training and employment stability $[19,22,23]$. Since most governments have a great interest in the rights and safety of workers, the social sustainability issue seems to become increasingly important to the 3PL providers who hire many pick-up and delivery people. Additionally, transport vehicles such as trucks and ships are additional important assets of 3PL providers, and thus their safety seems to be very important to 3PL providers as one of the social sustainability related issues.

Given the limited amount of research on social sustainability itself, research on the social sustainability based evaluation of 3PL providers is naturally very sparse. Moreover, this research was motivated by a real case of an e-commerce company which had an issue regarding the evaluation of the potential 3PL providers. Through the discussion with the managers of that company, we decided to consider social sustainability first when evaluating the 3PL providers to check whether potential 3PL providers are concerned about the social sustainability related issues.

The objective of this paper is to propose a framework and procedure for 3PL provider evaluation considering not only traditional cost and service competitiveness, but also social sustainability.

This paper is organized as follows: the related literature is summarized in Section 2, and then the social sustainability of 3PL providers is discussed in Section 3; in Section 4, the proposed approach is explained, and an illustrative example based on a real case is provided to show how the proposed evaluation approach works in Section 5; finally, Section 6 offers some concluding remarks and directions for future research.

\section{Literature Review}

The related literature can be classified into two categories: (1) evaluation criteria regarding the 3PL provider; and (2) evaluation methodologies.

\subsection{Evaluation Criteria for the 3PL Provider}

For the past two decades, numerous researchers have tried to identify the critical criteria for evaluating and selecting 3PL providers. The researchers usually used survey methodology to capture the important criteria. By investigating 131 firms, Fawcett and Smith [24] identified the following 5 criteria: quality, delivery, flexibility, cost, and innovation in services. Following their exploratory studies of Australian firms, Dapiran et al. [25] and Millen et al. [26] argued that cost is the most important criteria. Murphy and Daley [27] summarized 12 criteria for international freight forwarders selection as follows: expertise, reliability, ability to provide relevant information, attention, reputation, price, financial condition, convenience of use, services, geographical specialization, product specialization, and size. By investigating 126 firms in Singapore, Bhatnagar et al. [28] identified the following key criteria of the 3PL provider selection: service quality, cost, reputation, range of services, 
and relevant past experience. Lai et al. [29] determined that the cost and the asset are the most important criteria for 3PL provider evaluation by conducting a survey of 134 firms in Hong Kong. Yeung [30] also conducted a survey among 72 exporters in Hong Kong and identified 4 criteria: timeliness of services, price, quality of delivery, and customized supplementary services. Meanwhile, Mortensen and Lemoine [31] argued that the main criteria for selecting the 3PL provider are quality, reliability of delivery, market coverage, price, and competences. More recently, Aguezzoul [7] extensively reviewed the past literature focusing on the 3PL selection problem in terms of the criteria, the method, and the strengths and weakness of the methods.

As summarized above, most of the past related researches mainly focused on price (cost) and service quality when evaluating the 3PL providers. However, there have been a few trials adopting the social sustainability related criteria such as the labor or management policy related issues. Göl and Çatay [32] considered labor relations as one of five evaluation criteria, and Qureshi et al. [12] adopted the quality of management which helps strategic decision-making to have a long-term effect. Liu and Wang [13] used human resource policies along with twenty five other criteria for evaluating the 3PL providers. Leina et al. [33] chose safety of service as one of evaluation criteria when evaluating the fourth party logistics providers who play a role to integrate the resources, capabilities, and technology of a supply chain from the viewpoint of the 3PL provider. Also, Hsu et al. [34] considered labor union as a sub criterion of 'risk' because striking outsourcing service provider employees could disrupt transportation schedules. Xianlong and Yujie [35] adopted social effects of the company: enterprise culture construction, degree of social reputation, and brand building as one of the evaluation criteria. However, the social effects defined in their research focus more on reputation and brand image instead of social sustainability itself. Huang et al. [36] used training and management capability as evaluation attributes for logistics provider selection in a Taiwan automotive industry.

Although some of the past related researches tried to consider the social sustainability related criteria in evaluating the third-party logistics providers, most of them adopted only one or two individual criteria which mainly focused on labor relations or some related management policies (e.g., training, safety, etc.) inside company. In other words, other topics of social sustainability (i.e., philanthropy, occupational health, etc.) were not considered significantly in the past related researches, and there has been a lack of checking and considering the full range of social sustainability as the important criteria for evaluating the 3PL providers. More discussion on social sustainability follows in Section 3.

\subsection{Evaluation Methodologies}

As for the evaluation method, the multi-criteria decision-making (MCDM) methods were mainly used in the past related researches due to the availability of quantitative, qualitative, and multiple criteria that have to be considered in the decision process [37]. According to Aguezzoul [7], the main MCDM methods used in the case of 3PL provider selection are: analytic hierarchy process (AHP) [14,38-41], analytic network process (ANP) [9,11,34,42,43], technique for order preference by similarity to ideal solution (TOPSIS) [10,39,44], interpretive structural model (ISM) [42,44,45], multi-criteria optimization and compromise solution (VIKOR) [43,46], decision-making trial and evaluation laboratory (DEMATEL) [34,43], quality function deployment (QFD) [35,37], elimination and choice expressing reality (ELECTRE) [47], and utility theory [47]. Also, two different MCDM methods were applied together or a fuzzy sets theory (FST) is used with one of the MCDM methods as an integrated solution $[10,13,14,37,39,40,44,46,48,49]$. In terms of the number of publication from 1994 to 2013, AHP, ANP, and TOPSIS were chosen as the top three MCDM methods for the 3PL provider evaluation and selection [7]. Because the literature on the 3PL provider evaluation method is extensive and too broad to be fully covered here, we focus on three frequently used MCDM methods: AHP, ANP, and TOPSIS here. Bottani and Rizzi [10] proposed a fuzzy TOPSIS approach to evaluate and select the most appropriate 3PL provider using nine criteria that included compatibility, financial stability, flexibility of service, performance, price, and others. Jharkharia and Shankar [11] utilized the ANP 
approach to select the optimal 3PL provider using four major criteria: compatibility, cost, quality, and reputation. Similarly, Göl and Çatay [32] used the AHP approach to evaluate and select 3PL providers for the Turkish automotive industry with respect to five criteria: general company considerations, capabilities, quality, client relationship, and labor relations. Efendigil et al. [40] proposed an integrated approach combining fuzzy AHP and ANN to evaluate and select the best third-party reverse logistics providers. In addition, Cheng and Lee [50] adopted the ANP approach to select the third-party reverse logistics providers for high-tech manufacturing in Taiwan. More recently, Ho et al. [14] proposed an integrated approach, combining quality function deployment and the fuzzy AHP to evaluate and select the optimal 3PL providers. They used six main criteria, which were cost, delivery, flexibility, quality, technology, and risk. For reference, Chai et al. [51] published a systematic review paper on the decision making techniques in supplier selection, and Aguezzoul [7] also summarized various evaluation and selection methods for the 3PL providers.

\subsection{Contribution of Research}

Unlike previous research, the unique contribution of our research can be found in the following: (1) the definition and evaluation criteria of social sustainability for 3PL providers are defined and summarized; and (2) social sustainability is considered to be one of the important criteria for evaluating the 3PL providers.

\section{Social Sustainability of 3PL Providers}

\subsection{Social Sustainability}

In general, social sustainability has been represented as the social dimension of sustainability, which concerns the impact that the organization has on the social systems within which it operates [52-55]. Recently, social sustainability has become of paramount importance in business because of the need for increased stakeholder awareness regarding not only 'where' the products are made and delivered but also 'how' and 'in what conditions' they are produced and delivered [56].

In contrast to other dimensions of sustainability such as economic and environmental ones, social sustainability has suffered from under development, and it has been not sufficiently operational to serve analyses, planning and innovation [57,58]. Related research has also argued that further development of social sustainability in terms of concept and scope is needed [59-61]. In particular, Colantonio et al. [62] mentioned that the concept of social sustainability has been under-theorized or often oversimplified in existing theoretical constructs, and no consensus seems to exist on what criteria and perspectives should be adopted in defining social sustainability. However, throughout our literature survey, we found a common argument about social sustainability that vagueness and a pluralism of definitions are appropriate and preferable over a single definition because of the complexity of the topic and the impossibility or undesirability of a common definition $[58,63,64]$.

In addition, for the evaluation criteria (i.e., indicators, measures) of social sustainability, many researchers have proposed different criteria, both quantitative and qualitative [65-68]. These criteria differ across industries and countries, although the majority are oriented toward business partner (e.g. supplier) performance $[55,69,70]$. Frequently used criteria for social sustainability from prior research are summarized in Table 1. 
Table 1. Main criteria of social sustainability.

\begin{tabular}{|c|c|c|c|c|}
\hline Category & Criteria & Definition & Measure & References \\
\hline \multirow{2}{*}{ Society Related } & Philanthropy & $\begin{array}{l}\text { The extent to which the } \\
\text { company actively } \\
\text { participates in aiding the } \\
\text { society through donations } \\
\text { and commercial initiatives }\end{array}$ & $\begin{array}{l}\text { The budget } \\
\text { percentage set aside } \\
\text { for philanthropy }\end{array}$ & {$[19,55,71-74]$} \\
\hline & $\begin{array}{l}\text { Investment in local } \\
\text { community }\end{array}$ & $\begin{array}{l}\text { The extent to which the } \\
\text { company actively } \\
\text { participates in aiding the } \\
\text { local community }\end{array}$ & $\begin{array}{l}\text { The budget } \\
\text { percentage invested } \\
\text { in the local } \\
\text { community }\end{array}$ & {$[72,75]$} \\
\hline \multirow{3}{*}{$\begin{array}{l}\text { Employee } \\
\text { Related }\end{array}$} & $\begin{array}{l}\text { Employee average } \\
\text { duration of stay }\end{array}$ & $\begin{array}{l}\text { The turnover rate indicating } \\
\text { the loyalty of employees }\end{array}$ & $\begin{array}{l}\text { The number of years } \\
\text { an employee remains } \\
\text { in the industry }\end{array}$ & {$[72,74,76]$} \\
\hline & Minority & $\begin{array}{l}\text { The distribution of } \\
\text { minorities }\end{array}$ & $\begin{array}{l}\text { The percentage of } \\
\text { minority employees }\end{array}$ & {$[72,77,78]$} \\
\hline & Average salary & $\begin{array}{l}\text { The extent to which the } \\
\text { company actively treats its } \\
\text { employees by payment }\end{array}$ & $\begin{array}{l}\text { The average } \\
\text { employee salary }\end{array}$ & {$[19,55,72,78-80]$} \\
\hline \multirow{4}{*}{$\begin{array}{l}\text { Management } \\
\text { Policy }{ }^{1} \text { Related }\end{array}$} & $\begin{array}{l}\text { Organizational } \\
\text { learning/training } \\
\text { process and program }\end{array}$ & $\begin{array}{l}\text { The existence, variety, and } \\
\text { level of the processes or } \\
\text { programs related to the } \\
\text { certification and } \\
\text { internal/external education }\end{array}$ & Qualitative measure & {$[58,72,74,80-83]$} \\
\hline & $\begin{array}{l}\text { Appraisal/Recognition } \\
\text { systems and } \\
\text { development }\end{array}$ & $\begin{array}{l}\text { The existence, variety, and } \\
\text { level of the system related } \\
\text { to employee appraisal and } \\
\text { recognition (e.g., peer } \\
\text { comparison, } \\
\text { multi-dimensional } \\
\text { performance measures) }\end{array}$ & Qualitative measure & {$[72,84,85]$} \\
\hline & $\begin{array}{l}\text { Human rights and } \\
\text { participation }\end{array}$ & $\begin{array}{l}\text { The existence and level of } \\
\text { the policy related to } \\
\text { employee rights and } \\
\text { participation (e.g., whistle } \\
\text { blowing, unions and } \\
\text { incentives) }\end{array}$ & Qualitative measure & {$[55,72,86-89]$} \\
\hline & $\begin{array}{l}\text { Occupational health } \\
\text { and safety }\end{array}$ & $\begin{array}{l}\text { The existence and level of } \\
\text { the policy related to } \\
\text { occupational health and } \\
\text { safety }\end{array}$ & Qualitative measure & $\begin{array}{c}{[19,55,67,72,80,85,} \\
90-92]\end{array}$ \\
\hline
\end{tabular}

\subsection{Definition and Evaluation Criteria of Social Sustainability for 3PL Providers}

As mentioned above, since a common definition is impossible or undesirable and the related criteria differ across industries, we need to newly define the concept and the related criteria of social sustainability regarding the 3PL partnership.

Thus, by examining the definition and criteria summarized in Section 3.1, social sustainability of the 3PL provider can be defined as follows:

- Social sustainability of the 3PL provider means to operate its 3PL services considering their impact on internal and external stakeholders (i.e., society and employees) in terms of welfare, safety, and wellness

We also need to generate the social sustainability related criteria for evaluating the 3PL providers. To do this, we select the frequently adopted criteria from past research from Table 1 with the help of practitioners working for either the shipper or the 3PL provider. Considering the number of references for each criterion and the opinion of the practitioners, philanthropy is selected from the 'society' 
category whereas the average salary is chosen from the 'employee' category. For the 'management policy' category, the following three sub-criteria are selected: organizational learning/training process and program, human rights and participation, and occupational health and safety. The selected five criteria including three sub-criteria are redefined in accordance with the business practice of the 3PL providers. In addition to these five criteria, we add two more criteria: price and customized service, from the traditional 3PL evaluation literature, and one more sub-criteria, vehicle safety, to the 'management policy' category considering the 3PL services. Since most of the 3PL services are conducted via various vehicles, the safety of those vehicles becomes more important. Specifically, any unexpected problems that occur with vehicles can cause damage to the brand image and reputation of 3PL providers. Also, the customized service indicates not the quality of service but the variety or flexibility of service which can respond to the customers' requests. Since the service quality can only be evaluated after experiencing the service, it cannot be used as a criterion in the current evaluation step.

The background of selecting the social sustainability related criteria of this research is depicted in Figure 1.

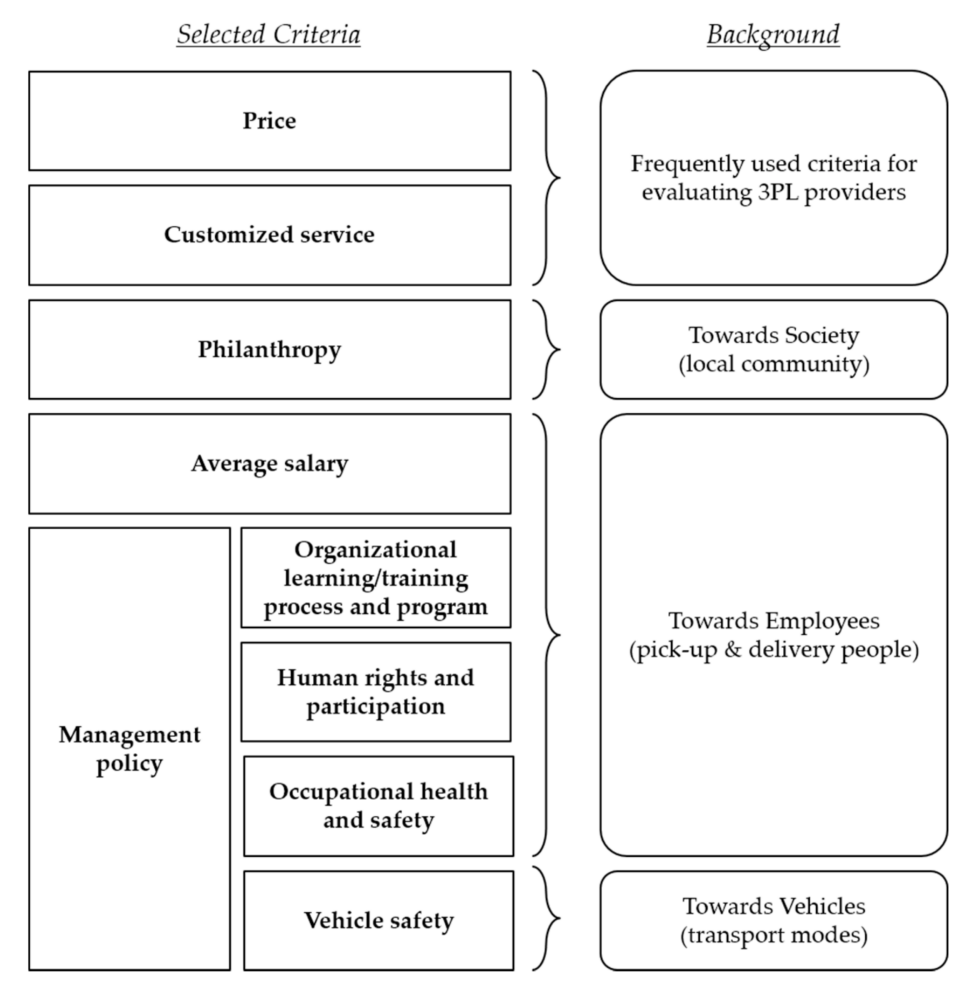

Figure 1. The background of selecting the evaluation criteria for the third-party logisitics (3PL) provider.

The aforementioned evaluation criteria for 3PL providers are summarized in Table 2. In the next section, the proposed evaluation approach utilizing these criteria are explained. 
Table 2. Evaluation criteria of 3PL provider.

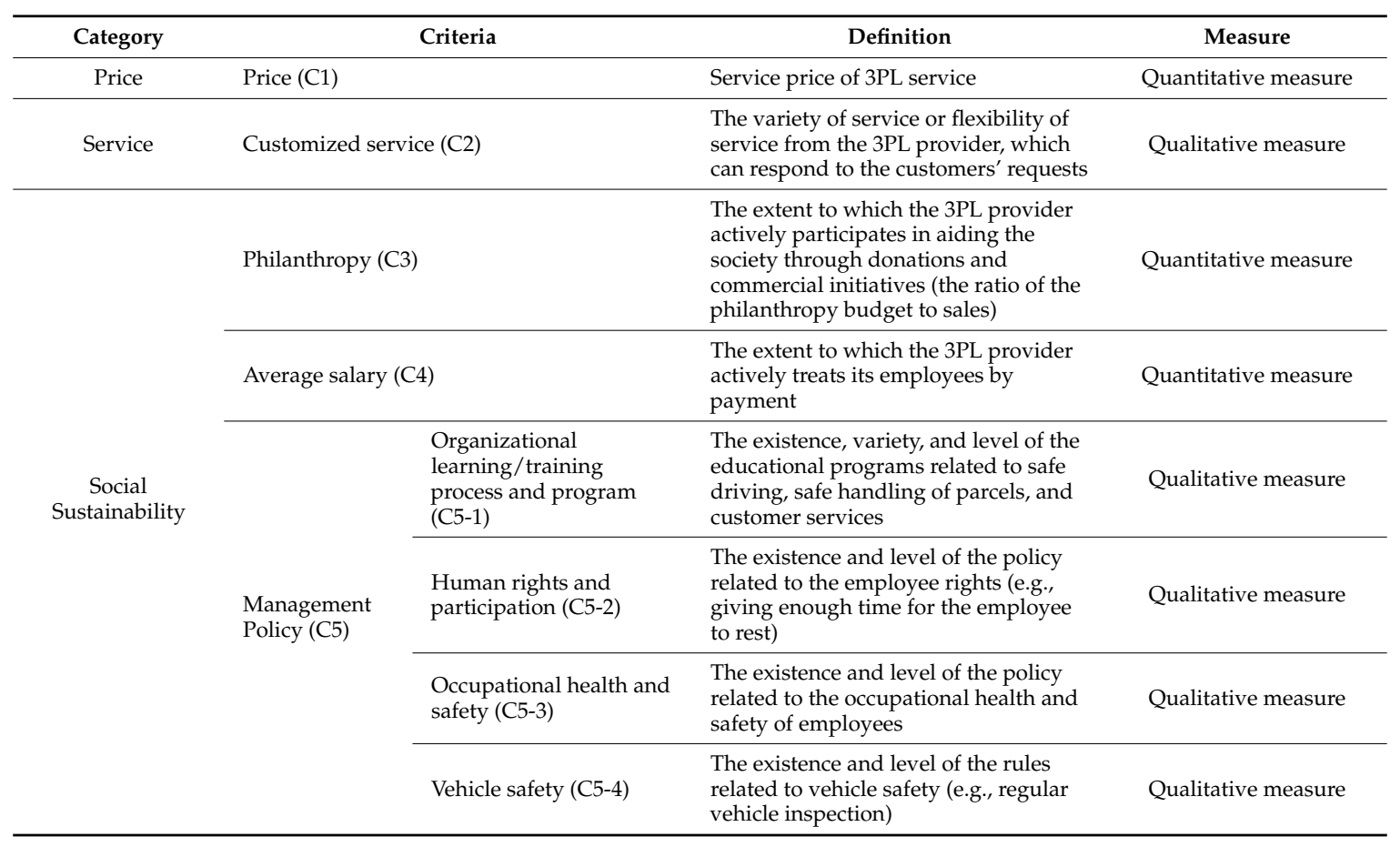

\section{Proposed Approach}

Once the evaluation criteria are developed, an evaluation framework should be determined. Among many MCDM methodologies, we chose an AHP as our main evaluation framework due to its ease of use and well-known applicability in various real-world cases [94-97]. The AHP has been widely used for decision-making problems with multiple criteria and alternatives and was first developed by Saaty [98]. Even if the traditional AHP requires precise judgments from decision-makers, it is not always possible to accomplish that in practice [99]. When evaluating criteria or alternatives, decision-makers very naturally provide uncertain answers rather than precise answers [100]. Additionally, we can find that a decision-making problem itself includes a high degree of fuzziness and uncertainties. To overcome this difficulty, fuzzy theories have been adapted to the AHP, and this fuzzy AHP has been applied in many selection and evaluation problems [101,102]. In this research, we adopt a fuzzy AHP to translate the verbal expressions of evaluators into numerical ones for qualitative criteria such as customized service and human rights and participation.

The first step of the fuzzy AHP is to construct the decision hierarchy. This hierarchy is usually constructed from the goal of the problem (top level), through the evaluation criteria/sub-criteria (intermediate level), to the list of 3PL providers (bottom level). Since most decision-makers cannot simultaneously handle more than seven to nine factors when making a decision [103], most of the past research recommended four to five criteria to make a decision hierarchy [101,104]. On the assumption that there are three alternative 3PL providers, the hierarchy of our problem is depicted in Figure 2.

In Figure 2, to compute relative importance systematically and avoid handling more than five criteria at the same time, we use a sub-criteria level of the management policy. Thus, we need to conduct the assessment of five main criteria first and then assess the four sub-criteria. After the relative weights of both criteria and sub-criteria are determined, we can proceed to the assessment of companies in the alternative level. The assessment of criteria is performed by pair-wise comparison. In general, there are two different cases of pair-wise comparison of criteria: (1) pair-wise comparison of qualitative criteria and (2) pair-wise comparison of quantitative criteria. The former is used to assess the qualitative criteria (e.g., customized service or occupational health and safety) measured by survey or interview of the decision-makers, whereas the latter is for assessing the quantitative criteria (e.g., 
the proposed price of 3PL service or the average employee salary) measured by the given numerical values. For the qualitative criteria, the decision-makers can specify preferences in the form of an AHP numerical pair-wise comparison introduced by Saaty [98]. If the decision-makers cannot choose their preferences by numerical values, they can also express their preferences in natural language. In this research, triangular fuzzy numbers $(\widetilde{1}, \widetilde{3}, \widetilde{5}, \widetilde{7}, \widetilde{9})$ are used to indicate the relative importance of each pair of elements. A triangular fuzzy number $\widetilde{a}$ can be defined by the closed interval $[l, u]$ including its mean $m$ as follows:

$$
\mu_{\widetilde{a}}(x)=\left\{\begin{array}{c}
\frac{x-l}{m-l}, l \leq x \leq m, \\
\frac{u-x}{u-m}, m \leq x \leq u, \\
\text { 0,otherwise. }
\end{array}\right.
$$

Additionally, the triangular fuzzy number can be characterized by defining the interval of confidence level $\alpha$ as follows:

$$
\widetilde{a}^{\alpha}=\left[l^{\alpha}, u^{\alpha}\right]=[(m-l) \alpha+l, u-(u-m) \alpha] \forall \alpha \in[0,1]
$$

Equation (2) represents an $\alpha$-cut method that yields an interval set of values from a fuzzy number: the lower limit and upper limit of the fuzzy numbers with respect to $\alpha$-cut [105]. In general, the value of $\alpha$ is set between 0 and 1 . If $\alpha=0$, it indicates that the degree of uncertainty is greatest and the degree of confidence is least. If $\alpha$ is near 1 , the degree of uncertainty decreases and the degree of confidence increases. The triangular fuzzy numbers $(\widetilde{1}, \widetilde{3}, \widetilde{5}, \widetilde{7}, \widetilde{9})$, the corresponding membership function, and linguistic terms are shown in Figure 3 and Table 3.

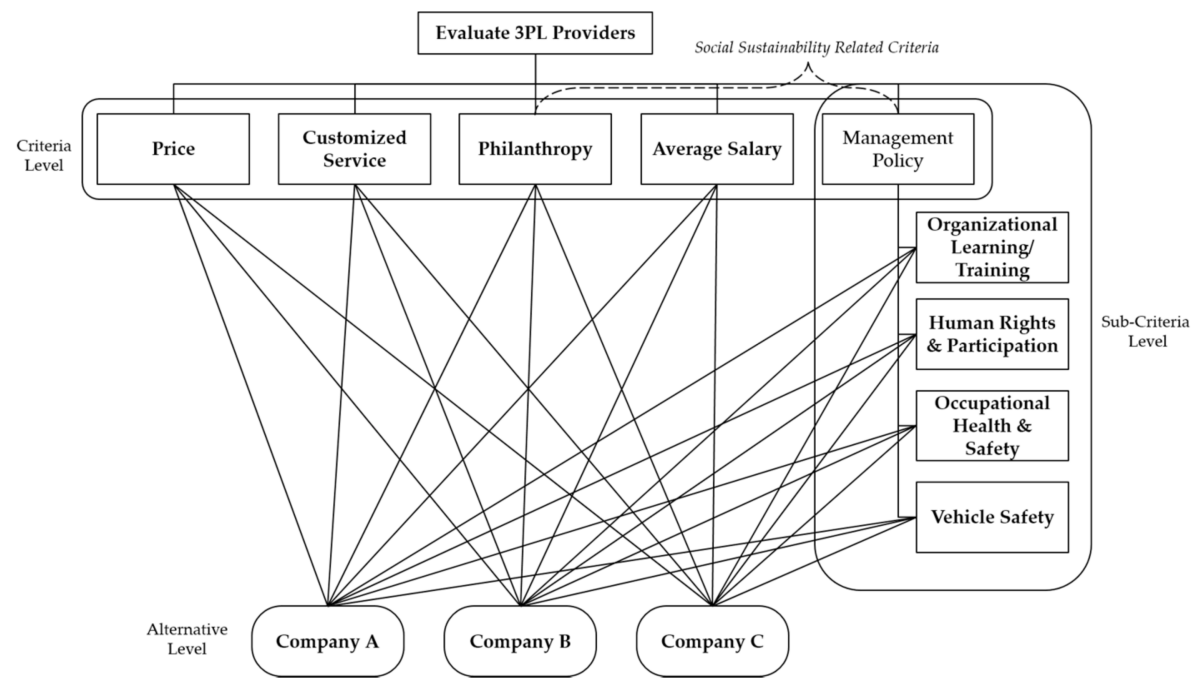

Figure 2. The hierarchy of the 3PL provider evaluation problem.

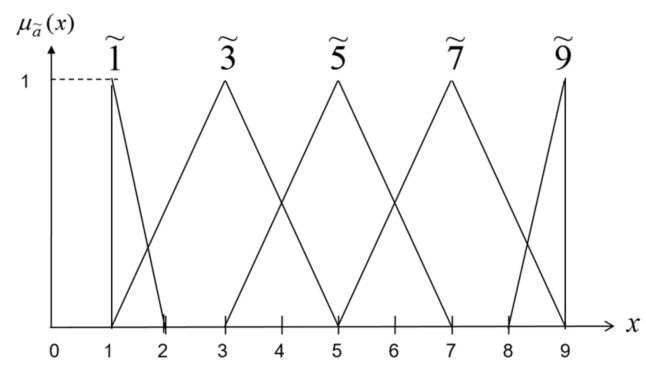

Figure 3. Membership functions for fuzzy numbers. 
Table 3. Fuzzy scale for judgment.

\begin{tabular}{ccc}
\hline \multicolumn{2}{c}{ Linguistic Judgments } & Fuzzy Number \\
\hline Equally important & Equally preferred & $(1,1,2)$ \\
Moderately more important & Moderately more preferred & $(1,3,5)$ \\
Strongly more important & Strongly more preferred & $(3,5,7)$ \\
Very strongly more important & Very strongly more preferred & $(5,7,9)$ \\
Absolutely more important & Absolutely more preferred & $(8,9,9)$ \\
\hline
\end{tabular}

Using the pair-wise judgment of the decision-maker and a fuzzy comparison matrix, $\widetilde{A}$ can be represented as follows:

$$
\widetilde{A}=\left[\begin{array}{cccc}
1 & \widetilde{a}_{12}^{\alpha} & \cdots & \widetilde{a}_{1 n}^{\alpha} \\
\widetilde{a}_{21}^{\alpha} & 1 & \cdots & \widetilde{a}_{2 n}^{\alpha} \\
\vdots & \vdots & \vdots & \vdots \\
\widetilde{a}_{n 1}^{\alpha} & \widetilde{a}_{n 2}^{\alpha} & \cdots & 1
\end{array}\right]
$$

where $\widetilde{a}_{i j}^{\alpha}=1$, if $i=j$, and $\widetilde{a}_{i j}^{\alpha}=\widetilde{1}, \widetilde{3}, \widetilde{5}, \widetilde{7}, \widetilde{9}$ or $\widetilde{1}^{-1}, \widetilde{3}^{-1}, \widetilde{5}^{-1}, \widetilde{7}^{-1}, \widetilde{9}^{-1}$, if $i \neq j$.

The constructed fuzzy comparison matrix $\widetilde{A}$ needs to be converted into a crisp comparison matrix. To do this, we apply the index of optimism, $\mu$, which also represents the decision-maker's attitude [106]. A larger value of $\mu$ indicates a higher degree of optimism. The index of optimism is a linear convex combination as follows:

$$
C\left(\widetilde{a}_{i j}^{\alpha}\right)=\mu a_{i j u}+(1-\mu) a_{i j l}, \forall \mu \in[0,1]
$$

where $C\left(\widetilde{a}_{i j}^{\alpha}\right)$ is the crisp value corresponding to $\widetilde{a}_{i j}^{\alpha}$ considering the index of optimism $\mu$.

By applying Equation (4) to the fuzzy comparison matrix $\widetilde{A}$, a crisp comparison matrix $A$ can finally be obtained.

In contrast to the qualitative criteria, a crisp comparison matrix $A$ can be directly obtained in regard to the evaluation for quantitative criteria [107]. If the criteria for comparison has a positive property (i.e., higher is better), a simple ratio between two elements can be used to directly construct a crisp comparison matrix $A$. On the other hand, a reciprocal ratio between two elements can be used for the negative criteria (i.e., lower is better). For example, let us assume that we are given four different prices from four different suppliers: $\$ 30 /$ unit from $A, \$ 40 /$ unit from $B, \$ 50 /$ unit from $C$, and $\$ 45 /$ unit from $\mathrm{D}$. Since the lower price is better (i.e., negative property), a comparison matrix $A$ can be formed as follows:

$$
A=\left[\begin{array}{cccc}
1 & \frac{40}{30} & \frac{50}{30} & \frac{45}{30} \\
\frac{30}{40} & 1 & \frac{50}{40} & \frac{45}{40} \\
\frac{30}{50} & \frac{40}{50} & 1 & \frac{45}{50} \\
\frac{30}{45} & \frac{40}{45} & \frac{50}{45} & 1
\end{array}\right]
$$

However, if we need to compare the profit, which has a positive property, a simple ratio can be used instead of a reciprocal ratio in matrix $A$.

Once the crisp comparison matrix $A$ is obtained, regardless of whether the criteria is qualitative or quantitative, a geometric mean method (Equation (6)) is utilized to compute their priorities [98]:

$$
g_{i}=\left(\prod_{j=1}^{n} C\left(\widetilde{a}_{i j}^{\alpha}\right)\right)^{1 / n} i=1, \ldots, n
$$

where $\widetilde{g}_{i}$ is the geometric mean of criterion or alternative $i$.

For each of the alternatives or criteria/sub-criteria, the weights can be computed as follows:

$$
w_{i}=g_{i} / \sum_{i=1}^{n} g_{i} \quad i=1, \ldots, n
$$


After we obtain the weights as explained above, it is necessary to examine the consistency of judgments by calculating the consistency ratio (CR) for each matrix. To obtain the CR, the consistency index $(\mathrm{CI})$ should be generated first using the following equation:

$$
\mathrm{CI}=\frac{\left|\lambda_{\max }-n\right|}{n-1}
$$

where $\lambda_{\text {max }}$ is the largest eigenvalue of $\widetilde{A}$ and $n$ is the size of matrix.

Next, the CR can be computed by dividing the CI by a value obtained from a table of Random Consistency Index (RCI), which is the average index for randomly generated weights [98].

$$
\mathrm{CR}=\frac{\mathrm{CI}}{\mathrm{RCI}}
$$

In general, if the CR is less than 0.1 , the comparisons are acceptable. Otherwise, it is not acceptable $[98,108]$. After the relative weights of criteria are determined, the priorities of the alternatives are also obtained from the pair-wise comparisons and the consistency check using the same procedure explained above. Finally, the priority weights of each 3PL provider can be calculated by weights per 3PL provider multiplied by weights of the corresponding criterion. The steps of the proposed approach explained above are shown in Figure 4.

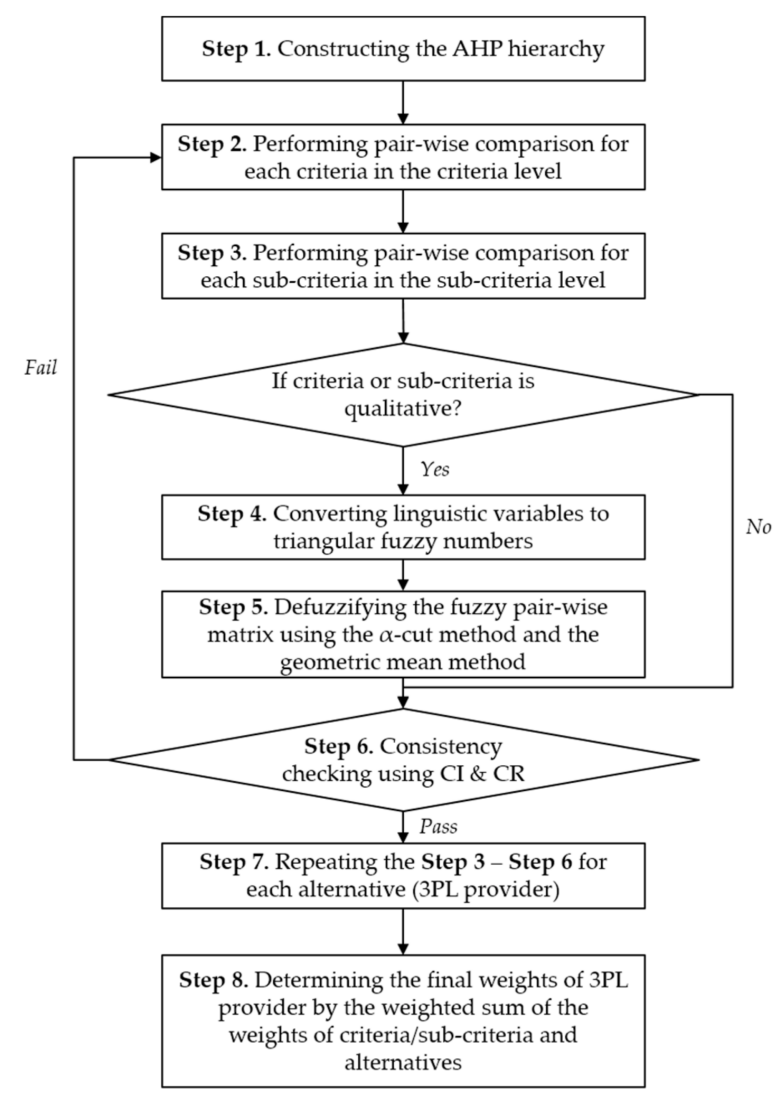

Figure 4. The steps of the proposed approach.

\section{Illustrative Example}

In this section, we consider an illustrative example in which the Korean branch of a global e-commerce company (G-company) wants to evaluate three potential 3PL providers (3PL-A, 3PL-B, 3PL-C) who can transport the ordered products (i.e., parcels) from various sellers to customers. Among many transport routes, G-company is now seeking for an appropriate 3PL provider who will mainly 
manage one of the important routes connecting the main distribution center (D/C) of G-company located in the central part of Korea and the capital area located in the north region of Korea. There are two different types of delivery from G-company to customers: (1) a direct delivery from each seller to each customer; and (2) delivery from each seller to each customer via the D/C of G-company. Usually, the latter is chosen for the delivery of best-selling items from the viewpoint of G-company. To do this, G-company asks the sellers who manage the best-selling items to stock up the given space of the $\mathrm{D} / \mathrm{C}$. Because G-company can manage and deliver the products easily from the D/C with the help of the chosen 3PL provider, this type of delivery is preferred. For the sake of clarity, the following are assumed without loss of generality.

- A product is packed in the box, and the price proposed by the 3PL provider is based on its standard size and weight: the size (=length + width + height) is under $80 \mathrm{~cm}$ and the weight is under $2 \mathrm{~kg}$ (i.e., $4.4 \mathrm{lb}$.)

- The price proposed by the 3PL provider includes delivery service from the D/C to customers only without any inventory management service in the D/C.

Three potential 3PL providers are all local companies that can deliver any product in Korea in accordance with the request of G-company. They run several large distribution centers in both the central and capital regions in Korea to transport parcels via a hub-and-spoke network. Because most of the parcels can be delivered within a day regardless of the 3PL provider due to the country's size, delivery speed cannot be an important factor for evaluation. Instead, price and customized service such as providing a mobile tracking system to both sellers and consumers are considered important evaluation criteria. Additionally, as with any other global e-commerce company, the management of G-company regards social sustainability as another important factor affecting the customers' recognition of the brand image. Thus, along with its own efforts for social sustainability, G-company wants its partners including 3PL providers to be concerned and to pursue social sustainability.

Before proceeding to the AHP analysis, we need to determine and collect the information regarding the quantitative criteria/sub-criteria such as the proposed price of 3PL service, the budget percentage invested in the local community, and the average employee salary. With the help of the decision-maker (i.e., a purchasing director) at G-company, we obtained the information shown in Table 4 . For confidentiality reasons, we manipulated both price and average salary properly.

Table 4. The collected information on the quantitative criteria/sub-criteria ${ }^{1}$.

\begin{tabular}{ccccc}
\hline Criteria/Sub-Criteria & Measure & 3PL-A & 3PL-B & 3PL-C \\
\hline Price (C1) & $\begin{array}{c}\text { The proposed price of 3PL service } \\
\text { (monetary unit) }\end{array}$ & $2.00 /$ box & $1.97 /$ box & $1.89 /$ box \\
\hline Philanthropy (C3) & $\begin{array}{c}\text { The budget percentage invested in the } \\
\text { local community (the ratio of the } \\
\text { philanthropy budget to sales) }\end{array}$ & $0.20 \%$ & $0.16 \%$ & $0.10 \%$ \\
\hline Average salary (C4) & $\begin{array}{c}\text { The average employee salary } \\
\text { (monetary unit) }\end{array}$ & 57,000 & 53,000 & 50,000 \\
\hline & 1 All of the information is dated as 2015.
\end{tabular}

As for the other (qualitative) criteria/sub-criteria, their relative weights were determined by asking the decision-maker at G-company who has experience in monitoring the 3PL industry and reviewing the related proposals to complete the survey in the middle of the AHP analysis.

In this example, $\alpha$ (confidence level on the judgments of the decision-maker) was set to 0.8 and $\mu$ (optimism index) was set to 0.6. Through some sensitivity analyses, we found that there were no significant changes in the final solutions (i.e., the final relative weights of criteria or alternatives) according to the setting of both parameters. This might be because those parameters are just used to convert the fuzzy judgement (i.e., linguistic judgments) of the decision-maker into the crisp number under the given preference of the decision-maker. Of course, the crisp numbers can change slightly 
due to the setting of both parameters. However, it seems to be difficult that only the setting of both parameters changes the rank of criteria and/or alternatives if there exists an apparent gap between criteria (or alternatives) in terms of the fuzzy judgement. Tables 5 and 6 show the fuzzy comparison matrices, their corresponding crisp comparison matrices, and the calculated weights for the criteria and sub-criteria levels. The judgments of decision-makers using Table 3 can be represented by Equation (2) as shown in the fuzzy comparison matrices of Tables 5 and 6.

Table 5. Fuzzy comparison matrix, crisp comparison matrix, and weights of the criteria level ${ }^{1}$.

\begin{tabular}{|c|c|c|c|c|c|c|c|c|c|c|c|}
\hline & \multicolumn{5}{|c|}{ Fuzzy Comparison Matrix } & \multicolumn{5}{|c|}{ Crisp Comparison Matrix } & Weigh \\
\hline $\mathrm{C} 1$ & 1 & {$[2.6,3.4]$} & {$[4.6,5.4]$} & {$[6.6,7.4]$} & {$[2.6,3.4]$} & 1 & 3.080 & 5.080 & 7.080 & 3.080 & 0.464 \\
\hline $\mathrm{C} 3$ & {$[1 / 5.4,1 / 4.6]$} & {$[1 / 3.4,1 / 2.6]$} & 1 & {$[2.6,3.4]$} & {$[1 / 3.4,1 / 2.6]$} & 0.205 & 0.348 & 1 & 3.080 & 0.348 & 0.086 \\
\hline $\mathrm{C} 4$ & {$[1 / 7.4,1 / 6.6]$} & {$[1 / 5.4,1 / 4.6]$} & {$[1 / 3.4,1 / 2.6]$} & 1 & {$[1 / 5.4,1 / 4.6]$} & 0.145 & 0.205 & 0.348 & 1 & 0.205 & 0.042 \\
\hline C5 & {$[1 / 3.4,1 / 2.6]$} & {$[1 / 1.2,1 / 1.0]$} & {$[2.6,3.4]$} & {$[4.6,5.4]$} & 1 & 0.348 & 0.933 & 3.080 & 5.080 & 1 & 0.201 \\
\hline
\end{tabular}

${ }^{1} \mathrm{CI}=0.059, \mathrm{RCI}=1.120, \mathrm{CR}=0.053(<0.1)$.

Table 6. Fuzzy comparison matrix, crisp comparison matrix, and weights of the sub-criteria level ${ }^{1}$.

\begin{tabular}{|c|c|c|c|c|c|c|c|c|c|}
\hline & \multicolumn{4}{|c|}{ Fuzzy Comparison Matrix } & \multicolumn{4}{|c|}{ Crisp Comparison Matrix } & \multirow{2}{*}{ Weight } \\
\hline & C5-1 & C5-2 & C5-3 & C5-4 & C5-1 & C5-2 & C5-3 & C5-4 & \\
\hline C5-1 & 1 & {$[1.0,1.2]$} & {$[1 / 3.4,1 / 2.6]$} & {$[1 / 5.4,1 / 4.6]$} & 1 & 1.120 & 0.348 & 0.205 & 0.099 \\
\hline C5-2 & {$[1 / 1.2,1 / 1.0]$} & 1 & {$[1 / 3.4,1 / 2.6]$} & {$[1 / 5.4,1 / 4.6]$} & 0.933 & 1 & 0.348 & 0.205 & 0.094 \\
\hline C5-3 & {$[2.6,3.4]$} & {$[2.6,3.4]$} & 1 & {$[1 / 3.4,1 / 2.6]$} & 3.080 & 3.080 & 1 & 0.348 & 0.251 \\
\hline C5-4 & {$[4.6,5.4]$} & {$[4.6,5.4]$} & {$[2.6,3.4]$} & 1 & 5.080 & 5.080 & 3.080 & 1 & 0.556 \\
\hline
\end{tabular}

As shown in Table 5, price is selected as the most important criteria for the evaluation of the 3PL providers, while customized service and management policies on social sustainability have similar weights and are ranked second and third in terms of the relative weight. Among four sub-criteria regarding the management policy, the vehicle safety was regarded as a top priority as shown in Table 6 . This is because vehicle safety directly affects the safety of both employees and products and is related to the reputation and service quality of G-company. Additionally, occupational health and safety are also regarded as another important sub-criterion. Throughout the comparison of similar processes against their alternatives, the final fuzzy AHP results can be obtained as shown in Table 7.

Table 7. Fuzzy AHP results ${ }^{1}$.

\begin{tabular}{|c|c|c|c|c|c|c|c|c|c|}
\hline \multirow{3}{*}{$\begin{array}{c}\text { Criteria } \\
\text { Weight } \\
\text { Sub-Criteria }\end{array}$} & \multirow{3}{*}{$\begin{array}{c}\mathrm{C} 1 \\
0.46\end{array}$} & \multirow{3}{*}{$\begin{array}{c}\text { C2 } \\
0.21\end{array}$} & \multirow{2}{*}{$\begin{array}{c}\text { C3 } \\
0.09\end{array}$} & \multirow{2}{*}{$\begin{array}{c}\mathrm{C} 4 \\
0.04\end{array}$} & \multicolumn{4}{|c|}{ C5 } & \multirow{4}{*}{$\begin{array}{l}\text { Final Weights } \\
\text { for Alternatives }\end{array}$} \\
\hline & & & & & \multirow[b]{2}{*}{ C5-1 } & \multicolumn{2}{|c|}{0.20} & \multirow{3}{*}{$\begin{array}{c}\text { C5-4 } \\
0.56\end{array}$} & \\
\hline & & & & & & C5-2 & C5-3 & & \\
\hline Weight & & & & & 0.10 & 0.09 & 0.25 & & \\
\hline 3PL-A & 0.325 & 0.441 & 0.435 & 0.356 & 0.493 & 0.207 & 0.468 & 0.260 & 0.361 \\
\hline 3PL-B & 0.330 & 0.415 & 0.348 & 0.331 & 0.393 & 0.599 & 0.441 & 0.635 & 0.395 \\
\hline 3PL-C & 0.344 & 0.144 & 0.217 & 0.313 & 0.114 & 0.195 & 0.091 & 0.105 & 0.244 \\
\hline CI & 0.000 & 0.032 & 0.000 & 0.000 & 0.036 & 0.032 & 0.021 & 0.049 & \\
\hline
\end{tabular}

From Table 7, the final relative weights of three 3PL providers are as follows: $0.361,0.395$, and 0.244 , and thus 3PL-B can be selected as a partner.

In addition, we conducted some sensitivity analysis using Table 7 to determine which criteria affect the current results from the viewpoint of 3PL-A and 3PL-C.

First, 3PL-C, the least preferred alternative, could have the same weight as 3PL-B when 3PL-A:3PL-B:3PL-C is $0.26: 0.26: 0.48$ in terms of price. This is based on the assumption that the weights for customized service are equal among alternatives (i.e., 1/3:1/3:1/3) and the weights for social sustainability related criteria are the same as the current results. In other words, when we assume that 3PL-A and 3PL-B propose the same price to G-company (the current proposed prices 
of two firms are close to each other), 3PL-C should have at least a weight of 0.48 . This means that if 3PL-A and 3PL-B propose the same price, 2 monetary units, 3PL-C should propose at most 1.083 monetary units $(=2 \times(0.26 / 0.48))$ to be selected. In short, even if 3PL-C can show the same capability regarding customized service as the other two competitors, it cannot be selected as a partner unless shortcomings in its social sustainability related management policy are remedied.

Second, 3PL-A has obtained a higher integrated weight (i.e., sum of the weight of each alternative considering the weights of criteria/sub-criteria) than the other competitors when considering only seven criteria/sub-criteria (i.e., from C1 to C5-3) except for C5-4. For reference, the integrated weight of 3PL-A considering $\mathrm{C} 1$ and $\mathrm{C} 2$ only can be calculated using Table 7 as follows: $(0.46 \times 0.325)+(0.21 \times 0.441)=0.242$. However, after adding the judgment regarding $\mathrm{C} 5-4$ to generate a final integrated weight, 3PL-A ranks second behind 3PL-B. Thus, 3PL-A needs to concentrate on improving its management policy on vehicle safety by building clear and concise rules and guidelines about how to manage and inspect their vehicles. Figure 5 shows the change of the integrated weight as we cumulatively add it from C1 to C5-4. As mentioned above, until C5-3, 3PL-A outperforms other competitors in terms of the integrated weight.

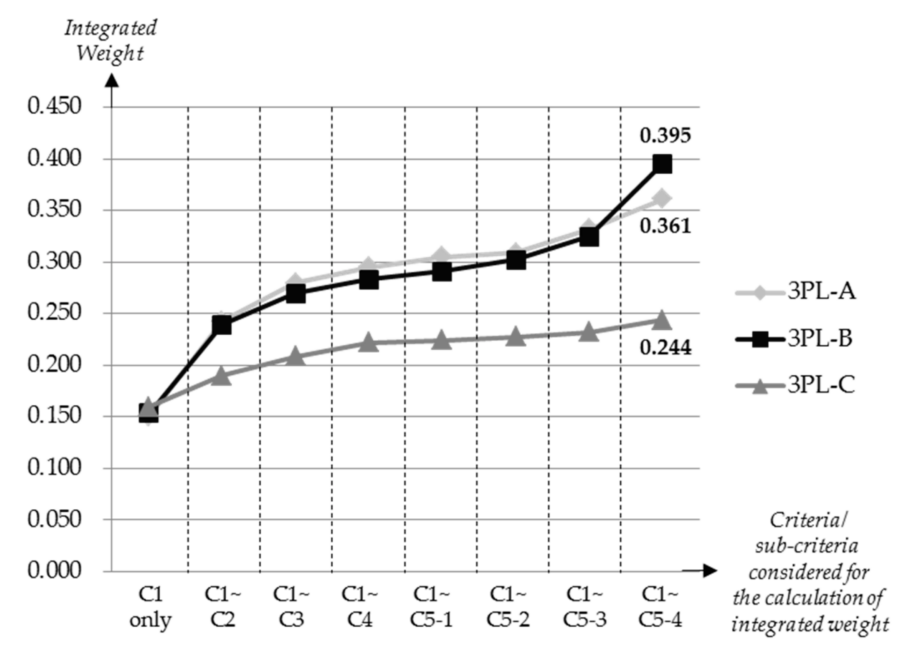

Figure 5. Change of the integrated weights of three 3PL providers.

\section{Conclusions}

In this paper, we addressed a 3PL provider evaluation problem considering traditional and social sustainability as one of the important evaluation criteria. Since the 3PL service is mainly dependent on both transport vehicles and employees, how to manage them from the viewpoint of social sustainability has become a critical issue. Thus, 3PL providers need to be concerned about not only the service price or quality but also issues related to social sustainability. Unlike most of the prior research, we adopted social sustainability into the evaluation of 3PL providers. To do this, we defined the social sustainability of 3PL providers and related evaluation criteria considering both past research and practitioners' opinions. Additionally, the fuzzy AHP was used as a main evaluation framework to help decision-makers judge the relative importance of each criteria or alternative using linguistic terms. To show the feasibility of the proposed criteria and evaluation framework, we presented the illustrative example based on a real-world case: the evaluation of three 3PL providers for an e-commerce company. The results showed that the proposed approach seems to be viable and to be a good alternative for evaluating the 3PL providers considering social sustainability. In addition, by changing the relative priorities of the evaluation criteria/sub-criteria in the proposed evaluation framework, decision-makers will be able to determine if such change might affect the final choice. 
However, this paper has some limitations. Before proposing the evaluation criteria and their measures of 3PL provider to practice, the pre-evaluation from both the related researchers and practitioners needed to be considered. Though the current evaluation criteria were chosen through an extensive literature review and they were applied to our example with the help of the managers of G-company, the pre-evaluation might be very helpful to check their feasibility and completeness objectively. Also, the environmental dimension was not considered in the current evaluation framework. Thus, for future studies, we need to extend our research by incorporating the constructs of an environmental dimension (i.e., purchasing more fuel-efficient vehicles, adopting the environmental management policies, retro-fitting a vehicle with more fuel-efficient engines, reducing vehicle idle times, etc.) into the current evaluation framework in order to consider a full range of sustainability together. Additionally, the proposed criteria and framework need to be tested using additional varied real-world situations including other service outsourcing cases. Also, the effect of setting of the membership functions of fuzzy numbers and/or both parameters needs to be further analyzed. Finally, the determined relative weights of the 3PL providers can be used to generate a transportation plan by allocating transporting amounts to each of 3PL providers considering those weights unless we need to select only one company.

Acknowledgments: The author would like to thank the anonymous reviewers for their helpful comments, which helped to improve this paper.

Conflicts of Interest: The author declares no conflict of interest.

\section{References}

1. Hertz, S.; Alfredsson, M. Strategic Development of Third Party Logistics Providers. Ind. Mark. Manag. 2003, 32, 139-149. [CrossRef]

2. Tyan, J.C.; Wang, F.; Du, T.C. An Evaluation of Freight Consolidation Policies in Global Third Party Logistics. Omega 2003, 31, 55-62. [CrossRef]

3. Jung, H.; Chen, F.; Jeong, B. Decentralized Supply Chain Planning Framework for Third Party Logistics Partnership. Comput. Ind. Eng. 2008, 55, 348-364. [CrossRef]

4. Bumstead, J.; Cannons, K. From 4PL to Managed Supply-Chain Operations. Logist. Transp. Focus 2002, 4, $18-24$.

5. Hannon, D. Third-Party Logistics: Maximizing Value of Outsource Partners Requires New Skills. Purchasing 2003, 132, 50-52.

6. Marasco, A. Third-Party Logistics: A Literature Review. Int. J. Prod. Econ. 2008, 113, 127-147. [CrossRef]

7. Aguezzoul, A. Third-Party Logistics Selection Problem: A Literature Review on Criteria and Methods. Omega 2014, 49, 69-78. [CrossRef]

8. Menon, M.K.; McGinnis, M.A.; Ackerman, K.B. Selection Criteria for Providers of Third-Party Logistics Services: An Exploratory Study. J. Bus. Logist. 1998, 19, 121.

9. Meade, L.; Sarkis, J. A Conceptual Model for Selecting and Evaluating Third-Party Reverse Logistics Providers. Supply Chain Manag. 2002, 7, 283-295. [CrossRef]

10. Bottani, E.; Rizzi, A. A Fuzzy TOPSIS Methodology to Support Outsourcing of Logistics Services. Supply Chain Manag. 2006, 11, 294-308. [CrossRef]

11. Jharkharia, S.; Shankar, R. Selection of Logistics Service Provider: An Analytic Network Process (ANP) Approach. Omega 2007, 35, 274-289. [CrossRef]

12. Qureshi, M.; Kumar, D.; Kumar, P. An Integrated Model to Identify and Classify the Key Criteria and their Role in the Assessment of 3PL Services Providers. Asia Pac. J. Mark. Logist. 2008, 20, 227-249. [CrossRef]

13. Liu, H.; Wang, W. An Integrated Fuzzy Approach for Provider Evaluation and Selection in Third-Party Logistics. Expert Syst. Appl. 2009, 36, 4387-4398. [CrossRef]

14. Ho, W.; He, T.; Lee, C.K.M.; Emrouznejad, A. Strategic Logistics Outsourcing: An Integrated QFD and Fuzzy AHP Approach. Expert Syst. Appl. 2012, 39, 10841-10850. [CrossRef]

15. Hassini, E.; Surti, C.; Searcy, C. A Literature Review and a Case Study of Sustainable Supply Chains with a Focus on Metrics. Int. J. Prod. Econ. 2012, 140, 69-82. [CrossRef] 
16. Lieb, R.C.; Lieb, K.J. The North American Third Party Logistics Industry in 2010: The Provider Ceo Perspective. Supply Chain Forum 2011, 12, 44-52.

17. Kudla, N.L.; Klaas-Wissing, T. Sustainability in Shipper-Logistics Service Provider Relationships: A Tentative Taxonomy Based on Agency Theory and Stimulus-Response Analysis. J. Purch. Supply Manag. 2012, 18, 218-231. [CrossRef]

18. Seuring, S.; Müller, M. From a Literature Review to a Conceptual Framework for Sustainable Supply Chain Management. J. Clean. Prod. 2008, 16, 1699-1710. [CrossRef]

19. Hutchins, M.J.; Sutherland, J.W. An Exploration of Measures of Social Sustainability and their Application to Supply Chain Decisions. J. Clean. Prod. 2008, 16, 1688-1698. [CrossRef]

20. Norris, C.B. Data for Social LCA. Int. J. Life Cycle Assess. 2014, 19, 261. [CrossRef]

21. Eskandarpour, M.; Dejax, P.; Miemczyk, J.; Péton, O. Sustainable Supply Chain Network Design: An Optimization-Oriented Review. Omega 2015, 54, 11-32. [CrossRef]

22. Large, R.O.; Kramer, N.; Hartmann, R.K. Procurement of Logistics Services and Sustainable Development in Europe: Fields of Activity and Empirical Results. J. Purch. Supply Manag. 2013, 19, 122-133. [CrossRef]

23. Boukherroub, T.; Ruiz, A.; Guinet, A.; Fondrevelle, J. An Integrated Approach for Sustainable Supply Chain Planning. Comput. Oper. Res. 2015, 54, 180-194. [CrossRef]

24. Fawcett, S.E.; Smith, S.R. Logistics Measurement and Performance for United States-Mexican Operations under NAFTA. Transp. J. 1995, 34, 25-34.

25. Dapiran, P.; Lieb, R.; Millen, R.; Sohal, A. Third Party Logistics Services Usage by Large Australian Firms. Int. J. Phys. Distrib. Logist. Manag. 1996, 26, 36-45. [CrossRef]

26. Millen, R.; Sohal, A.; Dapiran, P.; Lieb, R.; Van Wassenhove, L.N. Benchmarking Australian Firms' Usage of Contract Logistics Services: A Comparison with American and Western European Practice. Benchmark. Qual. Manag. Technol. 1997, 4, 34-46. [CrossRef]

27. Murphy, P.R.; Daley, J.M. Investigating Selection Criteria for International Freight Forwarders. Transp. J. 1997, 37, 29-36.

28. Bhatnagar, R.; Sohal, A.S.; Millen, R. Third Party Logistics Services: A Singapore Perspective. Int. J. Phys. Distrib. Logist. Manag. 1999, 29, 569-587. [CrossRef]

29. Lai, K.; Ngai, E.; Cheng, T. Measures for Evaluating Supply Chain Performance in Transport Logistics. Transp. Res. Part E Logist. Transp. Rev. 2002, 38, 439-456. [CrossRef]

30. Yeung, A.C. The Impact of Third-Party Logistics Performance on the Logistics and Export Performance of Users: An Empirical Study. Mar. Econ. Logist. 2006, 8, 121-139. [CrossRef]

31. Van Donk, P.D.; Mortensen, O.; Lemoine, O.W. Integration between Manufacturers and Third Party Logistics Providers? Int. J. Oper. Prod. Manag. 2008, 28, 331-359.

32. Göl, H.; Çatay, B. Third-Party Logistics Provider Selection: Insights from a Turkish Automotive Company. Supply Chain Manag. 2007, 12, 379-384. [CrossRef]

33. Leina, Z.; Tiejun, P.; Guoqing, Y. The Process Integration Evaluation Method of the Fourth Party Logistics using Fuzzy Theory. In Proceedings of the 2010 International Conference on Management of E-Commerce and E-Government, Chengdu, China, 23-24 October 2010; pp. 313-316.

34. Hsu, C.; Liou, J.J.; Chuang, Y. Integrating DANP and Modified Grey Relation Theory for the Selection of an Outsourcing Provider. Expert Syst. Appl. 2013, 40, 2297-2304. [CrossRef]

35. Ge, X.; Gu, Y. Research on Functional Logistics Provider Selection Based on QFD Modeling. J. Appl. Sci. 2013, 13, 3563-3568.

36. Huang, J.; Hu, M.H.; Wee, H. Evaluation of Lead Logistics Provider using the SMART Process: A Case Study in a Taiwan Automotive Industry. Oper. Supply Chain Manag. 2013, 6, 26-35.

37. Perçin, S. Evaluation of Third-Party Logistics (3PL) Providers by using a Two-Phase AHP and TOPSIS Methodology. Benchmarking 2009, 16, 588-604. [CrossRef]

38. Lehmusvaara, A.; Tuominen, M.; Korpela, J. An Integrated Approach for Truck Carrier Selection. Int. J. Logist. Res. Appl. 1999, 2, 5-20. [CrossRef]

39. Büyüközkan, G.; Feyzioğlu, O.; Nebol, E. Selection of the Strategic Alliance Partner in Logistics Value Chain. Int. J. Prod. Econ. 2008, 113, 148-158. [CrossRef]

40. Efendigil, T.; Önüt, S.; Kongar, E. A Holistic Approach for Selecting a Third-Party Reverse Logistics Provider in the Presence of Vagueness. Comput. Ind. Eng. 2008, 54, 269-287. [CrossRef] 
41. Falsini, D.; Fondi, F.; Schiraldi, M.M. A Logistics Provider Evaluation and Selection Methodology Based on AHP, DEA and Linear Programming Integration. Int. J. Prod. Res. 2012, 50, 4822-4829. [CrossRef]

42. Thakkar, J.; Deshmukh, S.; Gupta, A.; Shankar, R. Selection of Third-Party Logistics (3PL): A Hybrid Approach using Interpretive Structural Modeling (ISM) and Analytic Network Process (ANP). Supply Chain Forum 2005, 6, 32-46.

43. Liou, J.J.H.; Chuang, Y. Developing a Hybrid Multi-Criteria Model for Selection of Outsourcing Providers. Expert Syst. Appl. 2010, 37, 3755-3761. [CrossRef]

44. Kannan, G.; Pokharel, S.; Sasi Kumar, P. A Hybrid Approach using ISM and Fuzzy TOPSIS for the Selection of Reverse Logistics Provider. Resour. Conserv. Recycl. 2009, 54, 28-36. [CrossRef]

45. Govindan, K.; Palaniappan, M.; Zhu, Q.; Kannan, D. Analysis of Third Party Reverse Logistics Provider using Interpretive Structural Modeling. Int. J. Prod. Econ. 2012, 140, 204-211. [CrossRef]

46. Sasikumar, P.; Haq, A.N. Integration of Closed Loop Distribution Supply Chain Network and 3PRLP Selection for the Case of Battery Recycling. Int. J. Prod. Res. 2011, 49, 3363-3385. [CrossRef]

47. De Almeida, A.T. Multicriteria Decision Model for Outsourcing Contracts Selection Based on Utility Function and ELECTRE Method. Comput. Oper. Res. 2007, 34, 3569-3574. [CrossRef]

48. Işıklar, G.; Alptekin, E.; Büyüközkan, G. Application of a Hybrid Intelligent Decision Support Model in Logistics Outsourcing. Comput. Oper. Res. 2007, 34, 3701-3714. [CrossRef]

49. Li, F.; Li, L.; Jin, C.; Wang, R.; Wang, H.; Yang, L. A 3PL Supplier Selection Model Based on Fuzzy Sets. Comput. Oper. Res. 2012, 39, 1879-1884. [CrossRef]

50. Cheng, Y.; Lee, F. Outsourcing Reverse Logistics of High-Tech Manufacturing Firms by using a Systematic Decision-Making Approach: TFT-LCD Sector in Taiwan. Ind. Mark. Manag. 2010, 39, 1111-1119. [CrossRef]

51. Chai, J.; Liu, J.N.; Ngai, E.W. Application of Decision-Making Techniques in Supplier Selection: A Systematic Review of Literature. Expert Syst. Appl. 2013, 40, 3872-3885. [CrossRef]

52. Wood, D.J. Social Issues in Management: Theory and Research in Corporate Social Performance. J. Manag. 1991, 17, 383-406. [CrossRef]

53. Lafferty, W.M.; Langhelle, O. Sustainable development as concept and norm. In Towards Sustainable Development; Lafferty, W.M., Langhelle, O., Eds.; Palgrave Macmillan: London, UK, 1999; pp. 1-29.

54. Sharma, S.; Ruud, A. On the Path to Sustainability: Integrating Social Dimensions into the Research and Practice of Environmental Management. Bus. Strategy Environ. 2003, 12, 205-214. [CrossRef]

55. Mani, V.; Agarwal, R.; Gunasekaran, A.; Papadopoulos, T.; Dubey, R.; Childe, S.J. Social Sustainability in the Supply Chain: Construct Development and Measurement Validation. Ecol. Ind. 2016, 71, 270-279. [CrossRef]

56. McCarthy, I.P.; Lawrence, T.B.; Wixted, B.; Gordon, B.R. A Multidimensional Conceptualization of Environmental Velocity. Acad. Manag. Rev. 2010, 35, 604-626. [CrossRef]

57. Missimer, M.; Robèrt, K.; Broman, G.; Sverdrup, H. Exploring the Possibility of a Systematic and Generic Approach to Social Sustainability. J. Clean. Prod. 2010, 18, 1107-1112. [CrossRef]

58. Missimer, M.; Robèrt, K.; Broman, G. A Strategic Approach to Social Sustainability-Part 1: Exploring the Social System. J. Clean. Prod. 2017, 140, 32-41. [CrossRef]

59. Littig, B.; Grießler, E. Social Sustainability: A Catchword between Political Pragmatism and Social Theory. Int. J. Sustain. Dev. 2005, 8, 65-79. [CrossRef]

60. Kunz, J. Social Sustainability and Community Involvement in Urban Planning; University of Tampere: Tampere, Finland, 2006.

61. Cuthill, M. Strengthening the 'social' in Sustainable Development: Developing a Conceptual Framework for Social Sustainability in a Rapid Urban Growth Region in Australia. Sustain. Dev. 2010, 18, 362-373. [CrossRef]

62. Colantonio, A. Social Sustainability: A Review and Critique of Traditional Versus Emerging Themes and Assessment Methods. Available online: http:/ / eprints.lse.ac.uk/35867/ (accessed on 3 May 2017).

63. Dempsey, N.; Bramley, G.; Power, S.; Brown, C. The Social Dimension of Sustainable Development: Defining Urban Social Sustainability. Sustain. Dev. 2011, 19, 289-300. [CrossRef]

64. Missimer, M.; Robèrt, K.; Broman, G. A Strategic Approach to Social Sustainability—Part 2: A Principle-Based Definition. J. Clean. Prod. 2017, 140, 42-52. [CrossRef]

65. Carter, C.R.; Jennings, M.M. The Role of Purchasing in Corporate Social Responsibility: A Structural Equation Analysis. J. Bus. Logist. 2004, 25, 145-186. [CrossRef] 
66. Edgeman, R.; Neely, A.; Eskildsen, J.; Kozlowski, A.; Searcy, C.; Bardecki, M. Corporate Sustainability Reporting in the Apparel Industry: An Analysis of Indicators Disclosed. Int. J. Prod. Perform. Manag. 2015, 64, 377-397.

67. Tate, W.L.; Ellram, L.M.; Kirchoff, J.F. Corporate Social Responsibility Reports: A Thematic Analysis Related to Supply Chain Management. J. Supply Chain Manag. 2010, 46, 19-44. [CrossRef]

68. Yusuf, Y.Y.; Gunasekaran, A.; Musa, A.; El-Berishy, N.M.; Abubakar, T.; Ambursa, H.M. The UK Oil and Gas Supply Chains: An Empirical Analysis of Adoption of Sustainable Measures and Performance Outcomes. Int. J. Prod. Econ. 2013, 146, 501-514. [CrossRef]

69. Gugler, P.; Shi, J.Y. Corporate Social Responsibility for Developing Country Multinational Corporations: Lost War in Pertaining Global Competitiveness? J. Bus. Ethics 2009, 87, 3-24. [CrossRef]

70. Walker, H.; Seuring, S.; Sarkis, J.; Klassen, R.; Huq, A.; Stevenson, M.; Zorzini, M. Social Sustainability in Developing Country Suppliers: An Exploratory Study in the Ready made Garments Industry of Bangladesh. Int. J. Oper. Prod. Manag. 2014, 34, 610-638.

71. Global Reporting Initiative. Sustainability Reporting Guidelines Version 3.0. Available online: https://www. globalreporting.org/resourcelibrary/G3-Guidelines-Incl-Technical-Protocol.pdf (accessed on 3 May 2017).

72. Harik, R.; El Hachem, W.; Medini, K.; Bernard, A. Towards a Holistic Sustainability Index for Measuring Sustainability of Manufacturing Companies. Int. J. Prod. Res. 2015, 53, 4117-4139. [CrossRef]

73. Clarkson, M.E. A Stakeholder Framework for Analyzing and Evaluating Corporate Social Performance. Acad. Manag. Rev. 1995, 20, 92-117.

74. Hubbard, G. Measuring Organizational Performance: Beyond the Triple Bottom Line. Bus. Strategy Environ. 2009, 18, 177-191. [CrossRef]

75. Simón, C.; Martínez, J.L.; Agüero, A. Solidarity Day at Union Fenosa in Spain. Bus. Horiz. 2005, 48, 161-168. [CrossRef]

76. Villaseñor, L.E.P. Employee Turnover and Length of Stay in the Maquiladora Industry of Chihuahua, México; Harvard Graduate School of Education: Cambridge, MA, USA, 1994.

77. Oh, S.S.; Lewis, G.B. Stemming Inequality? Employment and Pay of Female and Minority Scientists and Engineers. Soc. Sci. J. 2011, 48, 397-403. [CrossRef]

78. Yakovleva, N.; Sarkis, J.; Sloan, T. Sustainable Benchmarking of Supply Chains: The Case of the Food Industry. Int. J. Prod. Res. 2012, 50, 1297-1317. [CrossRef]

79. Kolk, A. A Decade of Sustainability Reporting: Developments and Significance. Int. J. Environ. Sustain. Dev. 2004, 3, 51-64. [CrossRef]

80. Husgafvel, R.; Pajunen, N.; Virtanen, K.; Paavola, I.; Päällysaho, M.; Inkinen, V.; Heiskanen, K.; Dahl, O.; Ekroos, A. Social Sustainability Performance Indicators-experiences from Process Industry. Int. J. Sustain. Eng. 2015, 8, 14-25. [CrossRef]

81. Kleindorfer, P.R.; Singhal, K.; Wassenhove, L.N. Sustainable Operations Management. Prod. Oper. Manag. 2005, 14, 482-492. [CrossRef]

82. Folke, C.; Hahn, T.; Olsson, P.; Norberg, J. Adaptive Governance of Social-Ecological Systems. Annu. Rev. Environ. Resour. 2005, 30, 441-473. [CrossRef]

83. Westley, F.; Scheffer, M.; Brock, W.; Holmgren, M. Dynamic Interaction of Societies and Ecosystems—Linking Theories from Ecology, Economy and Sociology. In Panarchy: Understanding Transformations in Human and natural Systems; Gunderson, L.H., Holling, C.S., Eds.; Island Press: Washington, DC, USA, 2002; pp. 195-240.

84. Dreyer, L.C.; Hauschild, M.Z.; Schierbeck, J. Characterisation of Social Impacts in LCA. Int. J. Life Cycle Assess. 2010, 15, 247-259. [CrossRef]

85. Rajak, S.; Vinodh, S. Application of Fuzzy Logic for Social Sustainability Performance Evaluation: A Case Study of an Indian Automotive Component Manufacturing Organization. J. Clean. Prod. 2015, 108, 1184-1192. [CrossRef]

86. Sharma, S.; Vredenburg, H. Proactive Corporate Environmental Strategy and the Development of Competitively Valuable Organizational Capabilities. Strateg. Manag. J. 1998, 729-753. [CrossRef]

87. Jennings, M.M.; Entine, J. Business with a Soul: A Reexamination of what Counts in Business Ethics. J. Public Law Policy 1999, 20, 1-88.

88. Chow, W.S.; Chen, Y. Corporate Sustainable Development: Testing a New Scale Based on the Mainland Chinese Context. J. Bus. Ethics 2012, 105, 519-533. [CrossRef] 
89. Sancha, C.; Gimenez, C.; Sierra, V. Achieving a Socially Responsible Supply Chain through Assessment and Collaboration. J. Clean. Prod. 2016, 112, 1934-1947. [CrossRef]

90. Lee, P.K.; Lau, A.K.; Cheng, T. Employee Rights Protection and Financial Performance. J. Bus. Res. 2013, 66, 1861-1869. [CrossRef]

91. Carter, C.R.; Jennings, M. Purchasing's Contribution to the Socially Responsible Management of the Supply Chain. Available online: https:/ /www.instituteforsupplymanagement.org/files/sr/capsarticle_ purchasingscontribution.pdf (accessed on 3 May 2017).

92. Ciliberti, F.; Pontrandolfo, P.; Scozzi, B. Investigating Corporate Social Responsibility in Supply Chains: A SME Perspective. J. Clean. Prod. 2008, 16, 1579-1588. [CrossRef]

93. Glavič, P.; Lukman, R. Review of Sustainability Terms and their Definitions. J. Clean. Prod. 2007, 15, 1875-1885. [CrossRef]

94. Ho, W. Integrated Analytic Hierarchy Process and its applications-A Literature Review. Eur. J. Oper. Res. 2008, 186, 211-228. [CrossRef]

95. Ishizaka, A.; Labib, A. Review of the Main Developments in the Analytic Hierarchy Process. Expert Syst. Appl. 2011, 38, 14336-14345. [CrossRef]

96. Subramanian, N.; Ramanathan, R. A Review of Applications of Analytic Hierarchy Process in Operations Management. Int. J. Prod. Econ. 2012, 138, 215-241. [CrossRef]

97. Sipahi, S.; Timor, M. The Analytic Hierarchy Process and Analytic Network Process: An Overview of Applications. Manag. Decis. 2010, 48, 775-808. [CrossRef]

98. Thomas, S. The Analytic Hierarchy Process: Planning, Priority Setting, Resource Allocation; University of Pittsburgh: Pittsburgh, PA, USA, 1980.

99. Wang, Y.; Chin, K. A Linear Goal Programming Priority Method for Fuzzy Analytic Hierarchy Process and its Applications in New Product Screening. Int. J. Approx. Reason. 2008, 49, 451-465. [CrossRef]

100. Lee, A.H.; Kang, H.; Wang, W. Analysis of Priority Mix Planning for the Fabrication of Semiconductors under Uncertainty. Int. J. Adv. Manuf. Technol. 2006, 28, 351-361. [CrossRef]

101. Chan, F.T.; Kumar, N. Global Supplier Development Considering Risk Factors using Fuzzy Extended AHP-Based Approach. Omega 2007, 35, 417-431. [CrossRef]

102. Chamodrakas, I.; Batis, D.; Martakos, D. Supplier Selection in Electronic Marketplaces using Satisficing and Fuzzy AHP. Expert Syst. Appl. 2010, 37, 490-498. [CrossRef]

103. Miller, G.A. The Magical Number Seven, Plus or Minus Two: Some Limits on our Capacity for Processing Information. Psychol. Rev. 1956, 63, 81. [CrossRef] [PubMed]

104. Guneri, A.F.; Yucel, A.; Ayyildiz, G. An Integrated Fuzzy-LP Approach for a Supplier Selection Problem in Supply Chain Management. Expert Syst. Appl. 2009, 36, 9223-9228. [CrossRef]

105. Güngör, Z.; Serhadlıŏlu, G.; Kesen, S.E. A Fuzzy AHP Approach to Personnel Selection Problem. Appl. Soft Comput. 2009, 9, 641-646. [CrossRef]

106. Vahidnia, M.H.; Alesheikh, A.A.; Alimohammadi, A. Hospital Site Selection using Fuzzy AHP and its Derivatives. J. Environ. Manag. 2009, 90, 3048-3056. [CrossRef] [PubMed]

107. Saaty, T.L. How to make a Decision: The Analytic Hierarchy Process. Eur. J. Oper. Res. 1990, 48, 9-26. [CrossRef]

108. Ayağ, Z.; Özdemir, R. An Intelligent Approach to ERP Software Selection through Fuzzy ANP. Int. J. Prod. Res. 2007, 45, 2169-2194. [CrossRef]

(C) 2017 by the author. Licensee MDPI, Basel, Switzerland. This article is an open access article distributed under the terms and conditions of the Creative Commons Attribution (CC BY) license (http:/ / creativecommons.org/licenses/by/4.0/). 